\author{
Sylwia Kaczyńska \\ Dr nauk prawnych \\ Uniwersytet Ekonomiczny w Poznaniu \\ Sylwia.kaczynska@onet.eu
}

DOI: 10.35117/A_ENG_18_01_03

\title{
Safety and security. Civil liability of airport operator
}

\begin{abstract}
The airport operator is required to undertake numerous actions to avoid a crisis situations or personal injury and property damage of airport users as well as passengers. Comfortable and efficient service must be in harmony with the superior value - safety and security. The paper subject is an analysis of the responsibilities of the airport operator in the area of safety and security in the context of its civil liability in tort. Possible sources and principles of airport operator liability will be illustrated by the example of the passengers services process at the airport.
\end{abstract}

Keywords: Airport operator; Airport; Civil liability; Passenger

\section{Introduction}

An airport is often seen outside as one entity. In the functional sense, this is not a mistake, of course, because the airport is able to function properly, it is necessary to cooperate with entities and implement common and appropriate procedures for a given airport. However, it should be emphasized that the airport does not have legal personality, but it is owned by entities carrying out tasks at the airport. Each of the entities, including the handling agent, carrier or other entities, has specific activities and responsibilities associated with it. Public airport management in accordance with art. 174 para. 1 of the Aviation Act [31] covers the provision of air services related to the take-off, landing, and stop-over of aircraft, performed for air carriers and other aircraft users. The manager thus provides services to various entities - carriers, handling agents, and - in some cases - directly to passengers. The provision of these services may result in damage to the person or in the property that implies the civil liability of the managing body of the airport. Within aviation law, however, there are no regulations governing this issue, unlike the civil liability of the carrier $[45,25,18]$. The exception is the service of passengers with disabilities and reduced mobility - PRM [ang. Passengers with Reduced Mobility] for which the responsibilities and responsibilities of the manager are laid down in Regulation No 1107/2006 of the European Parliament and of the Council of 5 July 2006 concerning the rights of disabled persons and persons with reduced mobility when traveling by air [27]. In the remaining scope, the duties of the manager towards passengers may be drawn from the provisions of aviation law or from others in the area of influence of the manager. However, the matter of the civil liability of the manager, in particular, the principles of this responsibility, will be resolved in national law, on the basis of civil law.

\section{The scope of the manager's activity}

Airport management includes both operational activities, traditionally included in this type of activity, as well as commercial, commercial activities, which are currently an equally important area of airport managing activity (Currently, depending on the airport, commercial revenues for airports have up to $50 \%$ of their revenues) [4]. The manager's tasks illustrate the classic division of services provided at airports, i.e. airport and non-airport services. Nonaviation services cover a wide range of commercial services, including parking services, retail sales in stores in the public area (landside) and in the restricted area (airside), including duty- 
free shops, catering services, exchange offices. These services are derived from the basic activity to which the managers are appointed, i.e. airport services. One can also distinguish services that are not related to the basic activity of airports, such as advertising services, space rental, hotel services or entertainment (cinemas, tours) [9].In the field of airport (aeronautical) services provided by airports, airport management (operational depiction) and ground handling services are located. The basic activity of airport operators is precisely the airport activity whose direct beneficiaries are airport users, i.e. carriers, handling agents, and other entities. On the other hand, passengers are direct beneficiaries of non-business activities related to the management of terminal and parking infrastructure. It is a type of activity typical of enterprises and institutions managing infrastructure, and it includes maintenance of car parks, the infrastructure of buildings intended for commercial and office functions, surfaces in front of these buildings [12, ch. II and literature recalled there]. It should be emphasized that carriers or other airport users use the infrastructure on the basis of contractual relations (including per facta concludentia, i.e. the entity deciding to use the airport's services accepts its offer, which is, among others, the airport charges table) $[32$, p.275; 12, pp. 217 $219,33]$. The passenger, as a rule, does not combine the contractual relationship with the manager and uses the infrastructure due to the contract of carriage concluded with the carrier.

\section{Legal environment}

The above activities, and in particular airport services, are subject to broad legal regulations. Internationally, the Chicago Convention of 1944 [19] and the Chicago system based on it should be indicated. Detailed provisions on operational matters, including those imposed on airport operators, are included in the technical annexes to the Convention. In the context of the subject of this paper, please indicate in particular Annex 14, Airports, Volume. I Design and operation of airports [42], Annex 17, Protection of the International Civil Aviation against acts of unlawful interference [43], Annex 19, Security management [44]. European law regulates the operational aspects of airport management in a much broader and detailed way $[14,22,28]$. Polish aviation lawfully adapted to European and international law is based on the Act of 03.07.2002 aviation law. The purpose of these regulations is to ensure security for all entities using airport infrastructure. This security has two dimensions, which is expressed in art. 80 Polish Aviation Act. According to the wording of art. 80 PrLot "The airport manager is responsible for the safe operation of the airport, including the tasks related to airport security imposed on him." The term "safe operation of the airport" covers not only operational safety issues but also anti-terrorism security. At the same time, it should be assumed that the requirement of safe operation of the airport concerns both the strictly airport and non-aviation activities, where the manager is responsible as the owner or manager of the property [12, Chapter IV, Tobacco liability of the airport manager].

We should also mention the third area of responsibility of the airport managing body, which can be defined as corporate responsibility. The management of an airport is an economic activity and in this respect is subject to the provisions of commercial law. Sectoral considerations arise from the provisions of aviation law, which specify not only the responsibilities of airport managing bodies, but also the conditions that the operators must meet in order to be able to carry out the activities (According to Article 173 of the Airport Act, it is required to perform at the airports of public use in the field of airport management, and moreover, the provisions of the aviation law define the detailed conditions for obtaining the permit and the rules of conducting business by the airport managing bodies). Business law determines the conditions for running a business in a non-operational but economic dimension. There also appears the issue of property, which is the subject of state policy $[2 ; 45$, p. 365]. In Poland, the managers of public use airports operate in the form of commercial law companies (with the exception of the manager of Chopin Airport, which is a state-owned 
enterprise), whose characteristic feature is the pursuit of profit [29]. Thus, on the one hand, managers must implement the tasks imposed on them resulting from sectoral regulations, on the other hand, they must strive to meet the needs of airport passengers and users, as well as contractors and stakeholders, and at the same time must fulfill their obligations resulting from regulation of commercial law, which boils down to rational and financially and organisationally managing the company. Managers' obligations generate significant costs [34, 35], and the possibility of revenues is often determined by factors independent of them, such as the potential of the region. Security, however, is a superior value, as demonstrated by the aviation law system aimed at realizing this value, including through the need for the airport operator to obtain a certificate for public use. Its publication is preceded by a certification process, which is a verification of the entity's continued ability to operate safely (Article 160 (2) of the PrLot) [25]. The uniform certification procedure is effective from 1 January 2015 at all European airports that meet the requirements of the Regulation EC Regulation No. $139 / 2014$.

\section{Civil liability of the manager - source}

An event causing damage may occur in each of the areas of the manager's activity, however, the area of port operational safety (safety) and the area of preventing acts of unlawful interference (security) are the richest sources of damage to a person or property. The safety area includes activities related to ensuring operational safety at the airport, including, for example, maintaining the surface area of the ground movement - runway, taxiways, and parking spaces, conducting event prevention policy with lively nature, managing the apron and safety on the apron. The security area covers all activities related to the prevention of unlawful interference, including proper organization of checks on persons, baggage, cargo, mail, onboard supplies and airport supplies in connection with air transport or in the area of access from the public area to the security restricted area, organization of the system capacity, patrolling the airport. In the area of activities of the managing body that act as a by-vehicle, there may be events causing damage resulting from improper maintenance of the area in front of the terminals (e.g. icing), terminal infrastructure (e.g. no inspections of elevators, escalators, as well as incorrect marking of the floor after cleaning the floor), infrastructure maintenance parking lots (e.g., snowless and icy surfaces, faulty barrier). In this area, the manager should comply with generally applicable laws, which contain standards addressed to every typical company managing surfaces, including commercial areas.

\section{Civil responsibility in territorial terms}

When speaking about the responsibilities of the airport managing body, as well as its potential civil liability, it is necessary to determine the territorial area within its competence. The definition of the airport is introduced by the Chicago Convention in Annex 14. It is also included in several EU acts and in the Polish law, however, after the analysis of legal acts in the context of civil liability of the airport manager, including passengers, the definition contained in the said Regulation No. 1107 / 2006, according to which 'airport means terrain suitable for landing, take-off and maneuvers of aircraft, including auxiliary equipment necessary for the performance of these maneuvers in air traffic conditions and for the provision of air services, including ancillary equipment needed for the commercial carriage of passengers' ( Article 2 point j of the Regulation No. 1107/2006). Regulation No 1107/2006 also introduces the definition of a car park at an airport, which is 'a car park within the airport boundaries or under the direct control of the airport managing body which directly serves passengers using that airport' (Article 2 point k) Regulation No. 1107/2006). To sum up, the area where the manager will be obliged to take actions aimed at the safety of its users, including passengers, and where its liability may arise is the airport area including the 
landside and the reserved area (airside), including airport car parks, terminals and surfaces in front of terminals, including those in the restricted area. Sometimes this responsibility sometimes goes beyond the airport area, as exemplified by the prevention of crises with the lively nature, which are within the management responsibilities related to ensuring operational safety. According to the Doc 1937 Air Service Handbook [3], a bird collision at 0$60 \mathrm{~m}(0-200 \mathrm{ft})$ when landing and at 0-150 m (0-500 ft) during take-off should be considered as taking place at the airport. Therefore, if there is a collision at this level and the manager fails to fulfill his obligations, he will be the entity responsible for the damage $[16,8]$.

\section{The basis of the civil liability of the manager}

Apart from the contractual liability of the manager, the civil liability of the manager for the tort $[21,23]$ is required to be discussed. Without going into this theoretical and legal considerations in this area [12, Chapter III; 46], it should be pointed out that the basis of the manager's liability for a tort is Article 415 of the Civil Code. The manager responds on the principle of fault, thus, to hold him accountable, the manager should be found guilty. Similarly, a carrier or another airport user who incur costs related to the payment of compensation or repair of equipment, including aircraft (e.g. after a collision with a bird), applies for recourse to the manager. It is worth mentioning that the manager should perform his business with due diligence, which is required from a professional who manages a public use facility and provides services to carriers and other airport users. At the same time, it is emphasized in the literature that not only failure to apply due diligence, but also lack of knowledge, skills, inattention will be a professional guilt [5]. That is why procedures are so important, proper organization of work ensuring its high quality, proper development and preparation of infrastructure.

In view of the large number of entities operating at the airport, it is worth mentioning the obligation imposed on the manager as part of the SMS (Safety Management System) to ensure safe use and technical maintenance of the airport, which can only be filled by comprehensive regulation, implementation and operation of this area at the airport and cooperation of all entities operating at the airport. In a natural way, it is the manager that is the coordinator of activities in this field and the bonding of all services and their procedures. Pursuant to Annex II to Commission Regulation (EU) No 139/2014 of 12 February 2014 laying down the requirements and administrative procedures for aerodromes in accordance with Regulation (EC) No 216/2008 of the European Parliament and of the Council [25], the manager is obliged to ensure, among others that the airport management system should take into account the coordination and interoperability with the security procedures of other organizations operating or providing services at the airport, and these organizations have had security procedures in line with the applicable requirements. All procedures, as well as organizational issues, addressed not only to the employees managing the airport but also to all entities operating at the airport, are included in the operational manual of the airport. This is the basic document at the airport, containing the necessary elements to ensure the safety of flight operations. In the scope of security, such a document is the airport security plan. The manager should have confirmation that these entities have become familiar with the procedures.

This solution resembles the one functioning in Polish law resulting from art. $208 \S 1$ of the Labor Code, the obligation to cooperate between different employers, if the employees employed by these employers perform the work in the same place. These employers have, among others an obligation to appoint a coordinator supervising the safety and health at work of all employees working in the same place. The provisions regarding SMS do not exempt the manager from this obligation, which is obvious as they concern two different areas of responsibility. 


\section{Responsibility towards the carrier and other airport users}

Only by mentioning responsibility towards the above-mentioned entities, apart from the insurer's liability issues (the manager is not obliged to insure against civil liability), the manager may be liable for damage if he fails to fulfill the obligations imposed on him by law. As indicated above, as a professional, he must exercise due diligence in conducting his business. A very good example is the scope of tasks in the area of preventing crisis situations with the animated nature, including collisions with birds. Handbook of airport services doc 9137, in addition to standard activities like inspections and maintenance of runway and taxiways, recommends to the manager a comprehensive approach to the issue, including conducting formal and legal activities (e.g. appointing an animator) and technical (eg grass cuttings, review of buildings to remove sockets), external actions (including in the area of spatial development plans, for example to avoid the location of farmlands or garbage dumps around the airport) [12, pp. 144-146]. Only proper completion of tasks in each area will allow the manager to release civil liability in the event of damage.

\section{Responsibility towards the passenger}

As indicated above, this issue is interesting because, as a rule, no contract is concluded between the passenger and the manager during the passenger's journey, and clearly defined responsibilities of the manager towards passengers apply only to passengers with PRM status, from the moment they appear. at the airport in the so-called arrival and departure point [10]. Due to the scope of this regulation, however, this is an issue that needs to be discussed separately [13].

\section{Parking}

If the passenger uses a parking lot managed by the airport managing body, then a contractual relationship arises between these entities. The use of the car park is based on rules specified in the regulations (per facta concludentia), which include a price list for parking services. As a result of the conclusion of this contract, the Manager is obliged to provide a parking space on properly prepared parking infrastructure. Regardless of the contract for the parking service, the manager is obliged to take care of it in a manner that ensures the safe use of it (eg by snow removal). Damage to the car in the airport car park can lead to the manager's liability. Similarly, slipping on the pedestrian passenger's area may also contribute to the civil liability of the manager.

\section{The terminals}

At the later stage of the road around the airport, the passenger uses the infrastructure, moving from the parking lot to the terminal, through terminals, from the terminal to the aircraft. The use of this infrastructure is also covered by specific rules in the form of order regulations that the passenger must follow [15]. On the other hand, the manager is obliged to maintain all the mentioned infrastructure in a manner ensuring the safe use of it, ie he is obliged to review lifts, escalators, mark places where the surface may be wet, take care of snow removal and surface de-icing. These are tasks with direct beneficiaries of passengers. In the event of an event causing damage, in the absence of maintaining the principles of proper maintenance of infrastructure, the manager will be liable to the passenger in this respect.

\section{Luggage}

The passenger gives checked-in baggage at check-in, which is often mistakenly seen as entrusting luggage to the managing body of the airport. Article 17 paragraph 2 . The Montreal 
Convention of 1999 [20] provides that the carrier is liable for damage resulting from the destruction, loss or damage of the registered luggage if the event giving rise to the above occurred on board the aircraft or when the registered luggage remained under the care of the carrier. The key is to understand the concept of "under the care of the carrier." The carrier takes over the luggage registered under his protection at the moment of its registration, that is, sending it at the check-in place, where each piece of luggage is marked with a luggage tag. This issue is not in doubt, which confirms the sound of many conditions for the carriage of air carriers [36]. The care of the carrier lasts in principle until the baggage is picked up from the tape upon arrival. If the luggage is damaged, or if it is delayed to deliver it to the tape, as a rule, the responsible entity will be the carrier (usually operating through the handling agent). Possible civil liability in this area of the manager could be created if the infrastructure for transporting luggage would not be properly prepared or did not meet the requirements because the owner of this infrastructure is the manager.

\section{Security control}

The tasks in the field of security control at the airport are performed by the manager [30] through his own internal airport security service or he may commission them to an external entity - Specialist Armed Security Formation (so-called SUFO). At the security checkpoint, queues of waiting passengers are often found. The reasons for this are different: passengers arrive at the airport at the last minute; other times queues are caused by departures of planes at the same time or tightened security control procedures. The manager should anticipate such situations and set organizational procedures and provide the infrastructure so that it is possible to carry out a security check in a timely manner. In the face of too long waiting in the queue to control security, there is a risk of being late on the plane due to the too late appearance at the gate. In the case of passengers who have assigned checked-in luggage, the situation is even more complicated, because luggage cannot travel without a passenger (the obligation to combine checked-in luggage with passengers with boarding passes at every stage of the journey, called Reconciliation) [6]. Of course, it can not be expected that the controlling person will violate the control procedures so that the passenger will have time for the aircraft in this respect, the provisions are absolutely mandatory and safety is the paramount value. It also seems that it would be difficult to demonstrate to the employee the overzealousness resulting in slower service unless he exceeds his authority. Due to the fact that counteracting terrorism is a coherent system [6,14, 47], of which the airport is an element, including the procedures, equipment, and personnel employed [41], an employee can not be required to hurry. However, this does not mean that there is total discretion regarding the level of service in this area. According to the IATA guidelines, the required capacity at security gates should be 176 pax / h [1, 40]. With a properly provided infrastructure system and equipment, the manager should provide such a level of service and may require this level from SUFO (the manager may stipulate in the contract the level of passengers served within an hour and, for example, to prevent failure to meet these requirements by contractual penalties). However, if the airplane is late for reasons attributable to the manager and the passenger has complied with the applicable requirements and procedures, the passenger may claim damages not only from the carrier under the contract of carriage (the passenger could claim damages from the carrier under the contract for transport, if it appeared in time to screening, thus fulfilling its obligations to comply with the carrier's indications regarding the time of arrival at the airport, e.g. 2 hours before departure, the passenger has no influence on the security control procedures. in case of a recourse claim to the manager, if he is at fault), but it also seems to be directly from the manager. 


\section{Road to the plane}

So when is the passenger under the care of the carrier? This is a significant moment in the context of civil liability for injury or death of a passenger. Regarding baggage, as I mentioned above, the situation is clear, while some difficulties arise in the area of passengers. According to art. $17 \mathrm{sec} .1$ of the Montreal Convention "The carrier shall be liable for damage arising in the event of death or injury of a passenger only on condition that the accident that caused the death or injury took place on board the aircraft or during any of the operations related to embarking and disembarking." Difficulties of interpretation arise when interpreting the terms "getting in and out". While the US case-law recognizes the carrier's liability also for an accident at the terminal, the French courts have recognized that this is the time to start the contract, i.e. staying in the area of air transport risk, which means leaving the terminal building to the plane [24]. It seems that this interpretation should be adopted, considering that the carrier takes under the care of the passenger when he leaves the passenger terminal and goes to the plane, and this care ends when he leaves the airport plate after arrival [37, 38, 39]. After leaving the terminal building, the passenger goes to the plane. Apart from it, numerous activities are carried out to ensure the performance of the transport contract - safely and on time. These tasks are also carried out by the managers in the area of safety and security directly to the carrier.

\section{Summary}

Tasks imposed on the manager in connection with the performance of his aerodrome and around-aircraft activities are an element of a coherent security system - safety and security. They are designed to ensure safety, but also to comfort all airport users. However, in the event of a failure to fulfill the obligations and thereby causing damage to the person or property of the airport users, the manager may be exposed to civil liability. Situations in which a passenger who is also - besides the carrier - the main customer of an airport, can suffer damage caused by the direct action or omission of the manager, which may also contribute to improper or non-performance of the contract of carriage, are few. These include incidents in which the passenger is injured as a result of improper maintenance of infrastructure on the side of airside and landside, in particular, parking lots and passenger terminals. Another category of events may be situations related to the improper organization and improperly prepared infrastructure at security control points, which is performed by the manager (or an external entity on the principle of outsourcing). The last category will be tasked in the area of assistance to PRM passengers.

Compensation for other incidents, including damage or delays in baggage transportation or flight delays, the passenger will not seek the airport operator. The proper entity will be the air carrier with whom the passenger has a contract of carriage concluded and in this respect, the matter of determining who actually liable for the event causing the damage or with which the law combines the obligation to pay compensation is out of the passenger's interests. However, the carrier may make a claim against any entity, including the airport managing body (recourse claim). Such provisions are included in art. 37 of the Montreal Convention of 1999 [20], which has been fully incorporated into the Community legal order. Also Regulation 261/2004 of the European Parliament and of the Council of 11 February 2004 establishing common rules on compensation and assistance to passengers in the event of denied boarding, cancellation or long delay of a flight and repealing Regulation (ECC) No 295/91 [26], art. 13 provides for this possibility. And so the manager may be liable to the carrier for events contributing to improper performance or non-performance of the contract of transport, such as improperly functioning infrastructure for transporting luggage (eg the belt is damaged, luggage falls off the conveyor belt and is destroyed), poor organization of airport 
services causing delay in air operations, and, finally, improper conduct of lively nature policy, in particular in the field of bird strike prevention [11].

At the same time, the tasks performed by the manager and other entities should be distinguished. Thus, the owners of food and beverage outlets will be liable to the passenger in the event of food poisoning due to their activities, and the manager may only be liable to those entities as the landlord. Similarly, the passenger should be aware that the collection of luggage upon arrival is within the competence of the carrier who performs the task through a handling agent, and the manager may possibly be liable in the event of poor organization of the services at the airport or failure to provide proper infrastructure.

\section{Source materials}

[1] Airport Development Manual, 9th edition, 2004;

[2] Airport Economics Manual, Doc. 9562, second edition, 2006, s. 17 (2-1), p. 2.1.

[3] Airport Services Manual, Doc 9137, Part 3, Bird Control and Reduction.

[4] Czernicki F., Skoczny T. (red.), Usługi portów lotniczych w Unii Europejskiej i w Polsce a prawo konkurencji i regulacje lotniskowe, Warszawa 2010, s. 67

[5] Dubis, W. (2016). W: Gniewek, E. i Machnikowski, P. (red.). Komentarz KC. Warszawa: C.H. Beck. Komentarz do art. 415 kc., Nb 18

[6] Encyklopedia terroryzmu, tytuł oryginału: International Encyklopedia of Terrorism, Warszawa 2004

[7] Galicki Z., Terroryzm lotniczy w świetle prawa międzynarodowego, Warszawa 1981;

[8] Jaworek K., A. Konert, Szarama P., Sznajder J.: Problematyka odpowiedzialności Skarbu Państwa oraz innych podmiotów za szkody wyrządzone na skutek zderzenia statków powietrznych ze zwierzętami. „Ius Novum” 2014, nr 1, s. 143-162

[9] Jurkowska A., Zasady wyznaczania rynków usług portów lotniczych w sprawach z zakresu ochrony konkurencji i regulacji, w: Czernicki F., Skoczny T. (red.), Usługi portów lotniczych w Unii Europejskiej i w Polsce a prawo konkurencji i regulacje lotniskowe, Warszawa 2010, s. 56-71

[10] Kaczyńska S. Konert A., Jaworek K., Responsabilità per i passeggeri a mobilità ridotta nel trasporto aereo, praca zbiorowa w: El derecho aéreo entre lo público y lo privado. aeropuertos, acceso al mercado, drones y responsabilidad, monografia, Universidad Internacional de Andalucia, 2017

[11] Kaczyńska S. Przez port lotniczy do celu, czyli kto właściwie uczestniczy w procesie realizacji pasażerskiego przewozu lotniczego. Zadania i odpowiedzialność. 19 internetowy Kwartalnik Antymonopolowy i Regulacyjny 2017, nr 2(6), s. 19-36

[12] Kaczyńska S., (2016) Zarządzający portem lotniczym jako podmiot prawa prywatnego i publicznego. Zagadnienia wybrane; Warszawa: C.H. Beck

[13] Kaczyńska S., Konert A.; Łuczak K., Responsabilitá per i passeggeri a mobilitá ridotta nel transporto aereo, "Revista Latino Americana de Derecho Aeronáutico", 2016, Núm. 33, s. 12

[14] Kaczyńska S., Terroryzm lotniczy w międzynarodowym i unijnym systemie prawnym, Przegląd Komunikacyjny 2009, Nr 11-12, s. 19-27

[15] Kaczyńska S., Zarządzanie bezpieczeństwem przez zarządzającego portem lotniczym, w: K. Łuczak (red.), Zarządzanie bezpieczeństwem w lotnictwie cywilnym, Katowice 2016, s. 152-153

[16] Kaczyńska-Adamczyk, S. (2011). Airport operator and aircraft operator in case of bird strike. Relations, obligations and liability. Transport Problems, volume 6, issue 3, s. 51-59;

[17] Konert A., Odpowiedzialność cywilna przewoźnika lotniczego, s. 169 
[18] Konert A., Odpowiedzialność za szkodę na ziemi wyrządzoną ruchem statku powietrznego, Warszawa, 2014

[19] Konwencja o międzynarodowym lotnictwie cywilnym podpisana w Chicago dnia 7 grudnia 1944 r. - Konwencja chicagowska, Dz.U. z 1959, Nr 35, poz. 212 z późn. zm.

[20] Konwencja o ujednoliceniu niektórych prawideł dotyczących międzynarodowego przewozu lotniczego podpisana w Montrealu w dniu 28.05.1999 r. (Dz. U. z 2007 r. $\mathrm{Nr}$ 37, poz. 235)

[21] Łętowska, E. (red.) (2006). System Prawa Prywatnego, t. 5, Warszawa: C.H. Beck;

[22] Łuczak. K. (red.). (2016). Zarządzanie bezpieczeństwem w lotnictwie cywilnym. Katowice: Wydawnictwo Uniwersytetu Śląskiego

[23] Olejniczak A. (red.) (2009). System Prawa Prywatnego, t. 6, Warszawa 2009 oraz przywołana tam literatura i orzecznictwo

[24] Polkowska M., Szymajda I., Konwencja montrealska. Komentarz. Odpowiedzialność cywilna przewoźnika lotniczego, Warszawa 2004, str. 53

[25] Rozporządzenia Komisji (UE) nr 139/2014 z dnia 12 lutego 2014 r. ustanawiającego wymagania oraz procedury administracyjne dotyczące lotnisk zgodnie $\mathrm{z}$ rozporządzeniem Parlamentu Europejskiego i Rady (WE) nr 216/200862, Dz.Urz. UE L 44 z 14.2.2014, s. 1.

[26] Rozporządzenie Parlamentu Europejskiego i Rady nr 261/2004 z 11.02.2004 r. ustanawiające wspólne zasady odszkodowania i pomocy pasażerom w przypadku odmowy przyjęcia na pokład, odwołania lub dużego opóźnienia lotu i uchylenia Rozporządzenia (ECC) nr 295/91 (Dz. U. UE L z 2004, nr 46, s. 1)

[27] Rozporządzenie Parlamentu Europejskiego i Rady Nr 1107/2006 z dnia 5 lipca 2006 r. w sprawie praw osób niepełnosprawnych oraz osób o ograniczonej sprawności ruchowej podróżujących drogą lotniczą

[28] Siadkowski A., Tomasik A. (red.), Bezpieczeństwo i ochrona lotnictwa cywilnego, Poznań 2012

[29] The Ownership of Europe's Airports, 2016, ACI, dostępne na www.acieurope.org/component/downloads/downloads/4538.html, 22.10.2017 r.

[30] Ustawa z 30.6.2011 r. o zmianie ustawy - Prawo lotnicze oraz niektórych innych ustaw (Dz.U. Nr 170 poz. 1015)

[31] Ustawa z dnia 3 lipca 2002 r. - Prawo lotnicze, Dz. U. z 2017 r. poz. 959 i 1089

[32] Wolter A., J. Ignatowicz, K. Stefaniuk, Prawo cywilne. Zarys części ogólnej, Warszawa 2001, s. 275

[33] Wyrok SN z 6.10.2010 r., II CSK 210/10, OSNC 2011, Nr 5, poz. 59

[34] www.biznes.onet.pl/wiadomosci/kraj/zima-od-pazdziernika-do-kwietnia-rekordowekoszty-lotniska/1148m; 22.10.2017 r. 
[35] www.polskieradio.pl/42/273/Artykul/1739101,Poczta-Polska-wygrala-przetarg-naochrone-lotniska-Kontrakt-opiewa-na-30-mln-zl; 22.10.2017 r.

[36] www.ryanair.com/pl/pl/Przydatne-informacje/centrum-pomocy/warunki-ipostanowienia, 7.9.2016 r.

[37] Wyrok SN z 18.01.1971, I CR 330/70; Pozyskane z systemu Legalis

[38] Wyrok w sprawie Martinez Hernandez v. Air France 545 F.2d 279 (1st Cir. 1976), www.openjurist.org/545/f2d/279/martinez-hernandez-v-air-france, dostęp 26.02.2017 r.;

[39] Wyrok w sprawie Ricotta v. Iberia Lineas Aereas De Espana, 482 F. Supp. 497 (E.D.N.Y. 1979), pozyskano z www.law.justia.com/cases/federal/districtcourts/FSupp/482/497/2095565/, 26.02.2017 r.

[40] Wytyczne nr 4 Prezesa Urzędu Lotnictwa Cywilnego z dnia 19 lipca 2010 r. w sprawie wprowadzenia do stosowania dobrych praktyk $w$ zakresie ułatwień, www.ulc.gov.pl, 19.4.2017 r.

[41]Zajas S., Przeciwdziałanie zagrożeniom terrorystycznym na lotniskach, Zeszyty Naukowe AON 2007, Nr 2, s. 38-56

[42] Załącznik 14, Lotniska, Tom. I Projektowanie i eksploatacja lotnisk, Dz.Urz. ULC z 21.2.2011 r. Nr 2

[43] Załącznik 17, Ochrona Międzynarodowego Lotnictwa Cywilnego przed aktami bezprawnej ingerencji, Dz.Urz. ULC z 25.11.2011 r. Nr 18, poz. 109

[44] Załącznik 19, Zarządzanie bezpieczeństwem, Dz.Urz. ULC z 16.4.2014 r. poz. 28

[45] Żylicz M., Prawo lotnicze międzynarodowe, europejskie i krajowe, Warszawa, 2011;

[46] Żylicz, M. (red.), Prawo lotnicze. Komentarz, komentarz do art. 80

[47] Żylicz M., Terroryzm Lotniczy w świetle prawa międzynarodowego, PiP, 2005, Nr 9, passim. 